The Historical Journal, 64, 2 (2021), pp. 454-476 (c) The Author(s), 2020. Published by Cambridge University Press.

doi:10.1017/Soo18246X20000175

\title{
THE NATIONAL ORGANIZATION FOR WOMEN AND THE DEMOCRATIC PARTY IN REAGAN'S AMERICA*
}

\author{
JOE J. RYAN-HUME \\ The University of Glasgow
}

\begin{abstract}
A B S TRACT. This article explores the emergence of women in the United States as a liberal voting group in the I980s and the impact of this development on the power of liberalism, amid the Reagan revolution - an era often viewed as the apogee of conservatism. As the Republican party shifted in a more conservative direction in the I980s, gender started to correlate with partisan preference/election outcomes in enough contests to give credence to the belief that women were becoming a decidedly liberal voting bloc. Contemporaneously, the equality-seeking movements of the I96os and I97os began institutionalizing their operations and exploiting these demographic shifts, becoming more entrenched than ever within the internal politics of the Democratic party. The National Organization for Women $(N O W)$, the largest liberal women's group, proved to be particularly successful in this respect. Therefore, by presenting substantial archival evidence that liberal politicians and organizations remained a dynamic political force during the I980s, this article details the growing organizational prowess of NOW and examines how liberals resisted the conservative challenge to fashion a political approach suited to the 'Reagan Era'.
\end{abstract}

During the 1980s, the women's movement in the United States seemed to have stagnated. Multiple political commentators suggested that feminism had declined, subject to the same conservative forces that propelled President Ronald Reagan to two landslide election victories during the decade. The 1982 failure of the Equal Rights Amendment (ERA), a principal political objective of the women's movement, only reinforced this dreary assessment. Although

University Gardens, Glasgow GI 2 8QQJoe.Ryan-Hume@glasgow.ac.uk

* First, I am indebted to Marina Moskowitz, Phillips O'Brien, Dan Scroop, and Bruce Schulman, who each provided insightful and dedicated feedback through various iterations of this article. The completion of this research was also only made possible by generous funding from the Arts and Humanities Research Council (University of Glasgow) and the Fulbright Commission (Boston University), as well as fellowships at the Schlesinger Library, Harvard University, and the John W. Kluge Center, the Library of Congress. Finally, I would like to thank the editors and anonymous reviewers at the Historical Journal for their expert guidance and perceptive comments. 
a majority of Americans favoured the ERA, it was defeated by a highly effective mobilization of grassroots conservatism. Throughout the decade, accounts surfaced in newspapers, periodicals, and academic works with titles such as 'The failure of feminism', 'Post-feminism', and 'Who stole feminism?', and the 1980 s is often remembered as a decade of retrenchment for women more generally. ${ }^{1}$ Susan Faludi encapsulated this conventional viewpoint in her 1991 bestseller, Backlash: the undeclared war against American women. ${ }^{2}$ Detailing the defeat of the ERA, the ascent of the anti-abortion movement, and the rise of on-the-job sexual harassment and discrimination, Backlash painted a bleak picture of feminism in Reagan's America.

Faludi and other popular commentators, however, neglected important developments in feminist politics with enduring implications for liberalism in particular and electoral politics generally. By examining the activities of the National Organization for Women (NOW), the largest women's political organization in the US, this article details how the conservative backlash energized liberal women into greater political participation during the 1980 s, both at the ballot box and through effective coalition-building and electoral campaigns. ${ }^{3}$ Indeed, from 1979 to 1982 , which could reasonably be considered the height of Reaganism, NOW significantly professionalized its approach to politics and made the absence of women in the political arena a primary

1 Collection of titles from the National Organization for Women's 'Bad press/responses' folder, [n.d.], National Organization for Women papers (NOW papers), Schlesinger Library, Cambridge, MA, Collection MC666, box 43o, folder 9. For more on the backlash theory and stagnation argument, see Bradford Martin, The other eighties: a secret history of America in the age of Reagan (New York, NY, 2011), pp. 145-71; Julian E. Zelizer, 'Reflections: rethinking the history of American conservatism', Reviews in American History, 38 (2010), pp. 367-92; Ronnee Schreiber, Righting feminism: conservative women and American politics (Oxford, 2008); Susan M. Hartmann, 'Liberal feminism and the New Deal order', in Jonathan Bell and Timothy Stanley, eds., Making sense of American liberalism (Chicago, IL, 2012), pp. 202-28.

${ }^{2}$ Susan Faludi, Backlash: the undeclared war against American women (London, 1992).

3 NOW, established in 1966 by feminist activists, quickly emerged as the most powerful women's organization in the US. But it is important to note that the organization was criticized from the outset due to its membership and issue-orientation, which often benefited white, middle-class women more exclusively. With the white woman's experience often made synonymous with women's experiences, critics, such as bell hooks, claimed that the women's movement would 'give lip-service to the idea of sisterhood and solidarity between women but at the same time dismiss black women'. Still, as polls consistently demonstrated across decades, black women (and black men) supported NOW in higher proportions than white women or men. Moreover, NOW made efforts to address intersectionality throughout its existence, with 'ending racism' and 'promoting lesbian rights' as two of its six founding principles, and several of NOW's campaigns specifically tackled issues affecting working-class and minority women. Still, these criticisms persisted and should be kept in mind when considering the advances made by NOW in this period. See bell hooks, Ain't I a woman: black women and feminism (Boston, MA, 1981), pp. 8-9. Polling data in Jane Mansbridge, 'How did feminism get to be', American Prospect, 19 Dec. 2001. For nuance, see Stephanie Gilmore's Feminist coalitions: historical perspectives on second-wave feminism in the US (Chicago, IL, 2008), which provides a corrective to the view that the feminist movement was comprised of middle-class white women unconcerned with labour or racial justice issues. 
focus. NOW also established eighty-one new political action committees (PACs) across forty states to facilitate and fund the emergence of more female voices in politics, increased its membership threefold to over 220,000 and its annual budget fourfold to over $\$ 13$ million through effective mobilization strategies, and worked collaboratively with a diverse range of organizations, groups, and politicians to stem the tide of conservatism. 4

Focusing specifically on Reagan's first term, this study shows how NOW helped reshape the political landscape by altering its strategy to grapple with the more conservative political environment ushered in by Reagan's election in 1980. Indeed, the decade's more conservative climate necessitated the ongoing process of building ad hoc factional coalitions to protect or advance liberal interests. 5 Using diverse methods that covered the full spectrum of activism, from direct action protests to exerting pressure through electoral politics, broad liberal coalitions gelled around key issues during the decade, with NOW at the centre as the principal co-ordinating organization. For example, while the ERA struggle had a long history, the 1982 deadline for state ratification offered NOW a focal point to concentrate mobilization efforts at the beginning of the Reagan Era. And although the ratification battle ultimately failed, the organizing work of NOW provided a conduit for the hands-on engagement of numerous activist women in political campaigning, particularly at state and local level. ${ }^{6}$ Indeed, the ERA campaign, and the processes of grassroots organizing tied directly to it, reshaped the contours of women's political participation in the US and demonstrated the strength and breadth of public support for liberalism and affiliated 'women's issues' (those issues deemed, however stereotypically, to have particular importance for women, such as the ERA, abortion, and welfare). Moreover, this type of organizing was intertwined with developments in the Democratic party as liberals sought a political vehicle to resist the conservative challenge and protect established gains.

Illuminating the relationships forged between NOW and the Democratic party in Reagan's shadow, this article explores the processes of institution-

${ }^{4}$ NOW National Conference booklet, 8-1o Dec. 1982, NOW papers, MC496, box 21 , folder 9, p. 15 .

5 As both a political approach and a philosophical viewpoint, it should be stated at the outset that liberalism is a particularly elusive term. Indeed, historians have grappled with its meaning for decades given its protean and amorphous nature. Nonetheless, while it may not be systematic or logically coherent on every count, some key traits can be identified for the purposes of definition. Generally, liberals favour the use of government action to achieve a greater degree of social and political equality through legislative and programmatic remedies. While this is manifested in several ways in practice, this article views liberalism as a general political approach to expand opportunity, create an inclusive society, and address social and economic inequalities through government action; these views stand in contrast to conservatism and its emphasis on individualism, limited government and administrative decentralization, and market-based solutions to assure economic and political freedom.

${ }^{6}$ Eleanor Smeal, 'Backlash to Reagan's anti-women policies fuels ERA Countdown Campaign', National Press Club speech, 15 June 1981, NOW papers, MC496, box 201, folder 25 , p. 10. 
building and coalition formation in order to highlight the continuing influence of liberalism in the $198 \mathrm{os}$. It focuses on the nexus of grassroots activism, political ideology, and party politics to examine the processes through which NOW leveraged power in a hostile political environment and spotlights the broad coalitions that developed to affect change. Significantly, by analysing the emerging operational and organizational prowess of NOW, this study argues that liberalism remained a vibrant and dynamic political force during the 1980 s, despite what conventional orthodoxy holds. Indeed, by challenging the superficial interpretation of the decade that often juxtaposes conservative ascendancy with liberal decline, this article offers a re-evaluation of the period and contributes to the growing, but still underdeveloped, historiography of post-war liberalism.

To be sure, political historians of the 1980 os have often examined the decade through a Reagan prism; interpreting its politics as being shaped and dominated by the conservative movement he led. 7 While not wishing to dismiss the considerable achievements of post-196os conservative mobilization, the practical effect of this Reagan-centric approach has been to exaggerate the length and breadth of the Reagan Era, whilst diminishing the importance of liberals at the time. Crucially, there have been some recent, vital contributions to the historiography that offer a more nuanced appraisal. ${ }^{8}$ Lily Geismer's work, for example, explores the reorientation of modern liberalism and the Democratic party away from its roots in labour unions and urban machines towards the post-industrial metropolitan space by the $1980 \mathrm{os}$, where 'identity politics' - which stresses strong collective identities as the basis of political action - increasingly determined the shape and structure of voting coalitions. 9 Situated as part of this emerging scholarly trend, this article argues that the large-scale, and at least partially successful, mobilization of a major 'identitybased' group at the time showcases the power of this reconstituted liberalism in Reagan's America.

Importantly, the emergence of a new electoral dichotomy at the start of the decade would prove to be a catalyst for the organizing focus of NOW, bolstering their cause and spurring other liberal groups into co-ordinated action. As an administration report ominously highlighted, women were becoming

7 See, among others, John Ehrman, The eighties: America in the age of Reagan (New Haven, CT, 2005); Sean Wilentz, The age of Reagan: a history, 1974-2008 (New York, NY, 2008); Jeffrey Bloodworth, Losing the center: the decline of American liberalism, I968-1992 (Lexington, KY, 2013).

${ }^{8}$ John Ehrman, 'The age of Reagan? Three questions for future research', Journal of the Historical Society, 11 (2011), pp. 111-31. For such revision, see Timothy Stanley, Kennedy vs. Carter: the 1980 battle for the Democratic party's soul (Lawrence, KS, 2010); David Courtwright, No right turn: conservative politics in a liberal America (Cambridge, MA, 2010); Lily Geismer, Don't blame us: suburban liberals and the transformation of the Democratic party (Princeton, NJ, 2014).

9 Geismer, Don't blame us; Courtney Jung, 'Why liberals should value "identity politics", Journal of American Academy of Arts and Sciences, 135 (2006), pp. 32-9. 
'considerably more liberal and Democratic than men' in the Reagan Era. ${ }^{10}$ By November 1982, Reagan's presidential aide, Lee Atwater, warned that 'one of the most severe challenges facing the administration' - one that 'could lock the GOP into permanent minority status' - was this 'gender gap'. ${ }^{11}$ NOW's president, Eleanor Smeal, had been the first to identify and examine the 'gender gap' in any great depth, showing how women differed significantly in their 1980 presidential choice by electing to support Reagan far less than men did. ${ }^{12}$ Capitalizing on this, NOW then designed several campaigns throughout Reagan's first term to expand and exploit the emerging chasm, using it as leverage to influence several of the Democratic party's policy proposals and electoral campaigns. Significantly, for example, this article demonstrates how NOW used the electoral potential of the gap to convince Democrats to nominate the first woman to the vice-presidential slot in 1984 .

Moreover, the methods and strategies utilized by NOW and its allies through these campaigns would help lay the groundwork for significant future gains. We can see evidence for this by 1992, the so-called 'Year of the Woman', during which an unprecedented wave of women entered political office. ${ }^{13}$ Therefore, through examining the development of liberalism, with a focus on both grassroots organizing and the relationships established between Democratic politicians and NOW in particular, we can determine the significance of coalition-building and thereby present a more nuanced picture of the early Reagan years - one that places liberal women at the centre rather than on the periphery of Reagan's America.

The 1980 presidential election results revealed that 9.6 per cent fewer women than men voted for Reagan. Men supported the new president by a $56-3^{6}$

${ }^{10}$ Report quoted in Marisa Chappel, 'Reagan's “gender gap” strategy and the limitations of free-market feminism', Journal of Policy History, 24 (2012), pp. $115^{-34}$, at pp. $115^{-16}$.

${ }^{11}$ Lee Atwater, 'The gender gap: a postelection assessment', 23 Nov. 1982, in Julian E. Zelizer and Meg Jacobs, Conservatives in power: the Reagan years, I98I-I989: a brief history with documents (Boston, MA, 2011 ), pp. $114^{-1} 7$.

12 'Women vote differently than men, feminist bloc emerges in 1980 elections', National NOW Times, 1981, NOW papers, MC496, box 4 , folder 46 . Like the electorate it reflects, the gender gap is complex, but at a basic level, political observers defined it as the difference between the proportion of women and the proportion of men who support a particular politician, party, or policy position. See, among others, Carol M. Mueller, ed., The politics of the gender gap: the social construction of political influence (London, 1988); Pamela Conover, 'Feminists and the gender gap', Journal of Politics, $5^{\mathrm{O}}$ (1988), pp. 985-1010; Carole Kennedy et al., 'Explaining the gender gap in U.S. presidential elections, 1980-1992', Political Research Quarterly, $5^{1}$ (1998), pp. 311-39.

${ }_{13}$ In Congress, for example, a record 119 women stood for election in 1992, with 53 of them victorious. 'Summary of women candidates for selected offices, 1979-2014', Center for American Women and Politics (CAWP), www.cawp.rutgers.edu/sites/default/files/resources/can_histsum. pdf. 
margin over Jimmy Carter, while women gave Carter a narrow $47-45$ edge. ${ }^{14}$ Not only that, but 1980 was the first year that women voted in equal proportion to men, and demographic trends suggested that women would soon eclipse them (sure enough, in every presidential election since 1980, and in every congressional race since 1986 , the proportion of female voters has exceeded that of males). ${ }^{15}$ Together, these developments represented important breakthroughs in the political influence of women-albeit as male voting patterns were also becoming more partisan, and thus more influential as well. Surveying the political landscape after the election, Pat Reuss, the Women's Equity Action League's chief lobbyist, noted: 'People have not yet appreciated the election result. The same percentage of women and men voted. Yet [there] was an 8to-1o percent margin in choice. That is a mandate for us to continue our work. Women have separate concerns and they still want to see them pursued.' 16

The 1980 Republican platform represented a marked shift in the party's approach to several so-called 'women's issues' and liberals were quick to point to this as the reason for the gap's emergence. ${ }^{17}$ As the first major party to champion constitutional equality for women, the Republicans put the ERA in their platform as early as 1940 . But in 1980 , that commitment disappeared. ${ }^{18}$ In response, NOW organized around 12,00o people to march on the Republican convention in Detroit and directed activists to follow Reagan around the campaign trail with ERA placards. ${ }^{19}$ While not decisive, the Republican party's reversal on the ERA issue still had an impact on election day. According to one exit poll, only 32 per cent of the women favouring the ERA voted for Reagan. Carter, who had provided lukewarm support to the ERA, still attracted a clear majority of these voters. ${ }^{20}$

${ }^{14}$ While gender differences in presidential voting had occurred in the past, the margins were much smaller than in 1980 and generally favoured the Republican party instead; more women than men voted for Richard Nixon in 1960 ( 2 per cent) and Gerald Ford in 1976 (3 per cent). Henry C. Kenski, 'The gender factor in a changing electorate', in Mueller, ed., Gender gap, p. $5^{\mathrm{o}}$.

15 'Gender differences in voter turnout', CAWP, www.cawp.rutgers.edu/fast_facts/voters/ documents/genderdiff.pdf.

${ }^{16}$ Quoted in Anne N. Costain, 'Women's claim as a special interest', in Mueller, ed., Gender gap, p. 167 .

${ }_{17}$ 'Republican party platform', 15 July 1980, American Presidency Project (APP), www.presidency.ucsb.edu/ws/?pid $=25844$.

18 Liberal Republican, Senator Charles Mathias, tried to protect the ERA, saying that to drop it would 'imply that the party has backed away from its basic commitment to equal rights for women'. Charles Mathias, letter to colleagues, 1 July 1980, ERAmerica Records, Library of Congress, Washington DC, box 34 .

${ }^{19}$ NOW board meeting minutes, 6-7 Dec. 1980, NOW papers, MC496, box 4 , folder 46 , p. 2.

20 'Feminist bloc emerges', National NOW Times. Evidently, the gender gap is a multifaceted, multicausal phenomenon, and Jane Mansbridge produced a compelling contemporary argument challenging the extent of the ERA/gender gap connection in the 1980 elections. Jane 
At the same time as dropping the ERA from the Republican platform, Reagan backed the Human Life Amendment (HLA). The HLA was a proposed constitutional amendment that aimed to go further than simply overturning Roe v. Wadethe landmark 1973 Supreme Court case that enshrined abortion into federal law-by banning abortion and birth control measures outright. Supported by a number of conservative politicians, particularly Senator Orrin Hatch (R-UT.), Reagan's backing increased its legitimacy. In response, NOW launched a nationwide 'STOP HLA' campaign, with the slogan 'HLA is a KILLER'. ${ }^{21}$ By 1982, and in order to halt what they described as a 'right-wing attack' on abortion, NOW registered thousands of women to support pro-choice candidates in local elections. ${ }^{22}$ As historian Jon Shields observed, Reagan's election in 1980 marked the point when the parties took increasingly polarized stands on the issue of abortion, pushing many pro-lifers into Republican party politics. ${ }^{23}$ Indeed, conservative operative Richard Viguerie argued that 'the abortion issue is the door through which many people came into conservative politics'. ${ }^{24}$ Certainly, pro-choice supporters walked through the opposite door towards the Democrats, particularly after Reagan's platform pledge on the issue.

While gender differences in presidential voting were not entirely new, it was the magnitude evident from the election results and its persistence across Reagan's incumbency that was unprecedented. ${ }^{25}$ By the middle of Reagan's first term, for example, two separate Gallup polls, completed one year apart, demonstrated the staying power of the gap. In July 1982, the survey found that $5^{1}$ per cent of men approved of Reagan's job performance, while only 39 per cent of women did. By July 1983 , Gallup showed that while $5^{1}$ per cent of men still approved of Reagan's presidency, only 34 per cent of women did-a 17-point gap. ${ }^{26}$ Throughout Reagan's first term, an average of 9 per cent fewer women than men approved of his performance. ${ }^{27}$ Public Opinion showed that women gave these lower ratings almost uniformly across age and class groupings. ${ }^{28}$ Journalist Adam Clymer pointed out that Reagan's

E. Mansbridge, 'Myth and reality: the ERA and the gender gap in the 1980 election', Public Opinion Quarterly, 49 (1985), pp. 164-78.

${ }^{21}$ NOW board meeting minutes, $6-7$ Dec. 1980.

22 'Double victory for women's reproductive rights', memo to NOW activists, 20 Sept. 1982, NOW papers, $\mathrm{MC}_{49} 6$, box 203 , folder 7 .

${ }^{23}$ Jon A. Shields, 'Fighting liberalism's excesses: moral crusades during the Reagan revolution', Journal of Policy History, 26 (2014), pp. 103-20, at p. 110.

${ }^{24}$ Ibid., pp. 110-11; also see Daniel K. Williams, God's own party: the making of the Christian right (Oxford, 2010), pp. 153-71.

${ }_{25}$ The largest gender difference in presidential approval was just 3 points $(3$ per cent fewer women than men approved of Nixon's job performance). Kenski, 'The gender factor', p. $4^{8}$.

${ }^{26}$ Gallup polls, 8 July 1982 and 25 July 1983 , NOW papers, MC666, box 361 , folder 9 .

${ }^{27}$ Martin Gilens, 'Gender and support for Reagan: a comprehensive model of presidential approval', American Journal of Political Science, 32 (1988), pp. 19-49, at p. 19.

${ }_{28}$ Everett C. Ladd, 'Does Reagan have a problem with women?' Public Opinion, Dec. 1982, p. $4^{6 .}$ 
'women problem' seemed to be spreading throughout the Republican party. ${ }^{29}$ However, it was not enough to identify that women were becoming 'more liberal and more Democratic' following the 1980 elections. Rather, NOW and its allies, such as the National Abortion Rights Action League (NARAL), quickly recognized that they could use the gendered difference in voting patterns as leverage to better their own political position and, they believed, that of women more generally. $3^{\circ}$ Indeed, the gap may have simply remained an interesting statistical anomaly had these liberal organizations not effectively given it political meaning by seizing and promoting it so swiftly.

Taking the initiative in precisely this way, NOW drafted a booklet in early 1981 on the gap and its significance for wide distribution, titled 'Women can make the difference'. Designed as part of a conscious effort to push the gender gap into the political lexicon of journalists and politicians, the booklet included a chronological chart of 'Reagan's problem with women', pointing to various major polls that documented the issue under the heading 'Gender gap'. ${ }^{31}$ As the Washington Post's Judy Mann reported, by providing persuasive documentation that a 'women's vote' had finally emerged, the booklet was drafted to show Democrats that the opportunity was theirs, as long as they gave genuine support to women's issues. ${ }^{32}$ Months later, NOW revised the booklet to account for the gap's significance in the November, off-year elections. 33 Additionally, as a way to sustain interest, NOW began releasing a monthly 'Gender gap update' to several thousand reporters. 34

The gap also cut across partisan lines, with many liberal Republicans critical of Reagan's policies on equal rights, abortion, and other issues considered especially pertinent to women. The National Women's Political Caucus (NWPC) held a conference in 1983 where its Republican chair, Kathy Wilson, strongly urged Reagan to forgo a second term.35 As Wilson noted, Reagan's approach to women's issues led to a new 'coalescing among women's and minority groups' and prompted various non-partisan groups,

29 Adam Clymer, 'Women votes are a Reagan woe', New York Times (NYT), 19 Nov. 1981.

$3^{\circ}$ NARAL is the oldest US abortion rights advocacy group, founded in 1969 to oppose restrictions and expand access to abortion.

$3^{1}$ 'Women can make the difference', NOW report, 1981, NOW papers, MC496, box 209, folder 38 .

$3^{2}$ Judy Mann, 'Women', Washington Post (WP), 21 Oct. 1981.

33 According to the report, both parties viewed these elections as a test of Reagan's 'mandate', particularly the Virginia gubernatorial race. As NOW highlighted, exit polls demonstrated that women preferred Democrat Charles Robb by a substantial margin. 'Women can make the difference-revised', NOW report, Jan. 1982, NOW papers, MC496, box 209, folder 39 .

34 Kathy Bonk, 'Gender gap update', 26 Aug. 1982, NOW papers, MC725, box 54, folder 24.

35 In 1982, Wilson reported that a lot of women were saying 'I can't be a Republican anymore'. Quoted in 'Women and politics', CQ Researcher, 17 Sept. 1982, p. 2. 
including the NWPC, to get behind the liberal effort to defeat him. ${ }^{36}$ A central aspect of this effort was to focus attention on Reagan's campaign of welfare retrenchment.

\section{I}

As changing norms regarding sexuality, marriage, and workplace roles transformed US society, particularly after the 1960s, the economic fortunes of many women became increasingly intertwined with the welfare state through one or more of its major federal programmes-Social Security, Medicare, food stamps, housing benefits, and/or Aid to Families with Dependent Children (AFDC). 37 Yet Reagan swept to power arguing that government was actually the root of the nation's social and economic woes, famously declaring in his inaugural address that 'government is not the solution to our problem, government is the problem'. ${ }^{8}$ With this conviction, Reagan sought to discredit liberalism in general and the liberal commitment to welfare provision in particular. In this way, he skilfully exploited growing hostility across the country towards big government in the late 1970 os.

Significantly, in what economists Ann Mari May and Kurt Stephenson termed the 'inequalities of sacrifice', women constituted a majority of Reagan's targeted programmes: 61.6 per cent of Social Security, 64.8 per cent of Medicare, $5^{6.7}$ per cent of food stamps, 70 per cent of housing, and most significantly, 81.1 per cent of AFDC users.39 The welfare programme that suffered the largest decline in spending from 1980 to 1988 , at 11.2 per cent of its allocated budget, was also the one that had the highest percentage of women as clients or recipients, AFDC. A joint federal-state cash assistance programme enacted as part of a New Deal legislative wave in 1935, AFDC provided financial support for 'needy' children in the case of death, incapacity, or absence of a providing parent. As social norms regarding marriage and job roles changed rapidly, with rising divorce rates and more women in the labour market, the number of female-headed AFDC families increased considerably. $4^{\circ}$ Between 1961 and

\footnotetext{
$3^{6}$ Elizabeth Mehren, 'A faux pas by Reagan widens the gender gap', Los Angeles Times (LAT), 11 Aug. 1983 .

37 See, among others, James T. Patterson, America's struggle against poverty in the twentieth century (4th edn, Cambridge, MA, 20oo); Susan Ware, Beyond suffrage: women in the New Deal (Cambridge, MA, 1981).

$3^{8}$ Ronald Reagan, 'Inaugural address', 2o Jan. 1981, APP, www.presidency.ucsb.edu/ws/? pid $=43130$.

39 Ann Mari May and Kurt Stephenson, 'Women and the great retrenchment: the political economy of the 1980s', Journal of Economic Issues, 28 (1994), pp. 533-42, at p. 538.

$4^{\circ}$ A 1986 study noted the inability of 'social institutions to support the changing economic role of women'. Suzanne Bianchi, 'American women in transition', NYT, 30 Dec. 1986.
} 
1979, for example, the number of AFDC families headed by women more than quadrupled, from 635 ,ooo to 3 million..$^{1}$

Rising unemployment during Reagan's first term, which peaked at 10.8 per cent in 1982, also had a disproportionate effect on women, particularly as women comprised an estimated 'two-thirds of all minimum wage earners' in the country. ${ }^{2}$ A Congressional Press report determined that the recession was most severely felt by the growing numbers of single, divorced, and widowed women supporting themselves and their children through welfare and lowpaid work. 43 According to Ann Lewis, women were 'the miners' canaries of economic conditions: the first to feel the damaging effects of any ill winds'. 44 The National Advisory Council on Economic Opportunity declared, ominously, that this 'feminization of poverty' would be complete by the year 20oo, arguing that, by then, the poverty population would be composed entirely of women and their children. 45

In an effort to expand the gender gap, NOW honed in on this data and argued that Reagan's policies had not only failed to tackle the problem, but were actively accelerating it. ${ }^{6}$ Historically, there had been a class and racial divide between NOW and organizations such as the National Welfare Rights Organization (NWRO). 47 NOW's initial campaigns to 'liberate' women from the monotony of households was largely a middle-class endeavour and presented a false dichotomy to groups like the NWRO, who fought instead for a guaranteed adequate income, regardless of whether women worked in factories or were at home raising children. $4^{8}$ Moreover, while NOW's Bill of Rights demanded 'that poor women be given the same access to opportunities as men, without prejudice based on their status as mothers', black women, and black men for that matter, clearly had far less access to opportunity, regardless of parental status.

Yet, by the 1980 , with both the reality of Reagan's welfare cuts on full display and the NWRO no longer in existence, NOW assumed the mantle of welfare state defender, laying blame for the poverty situation squarely at Reagan's

$4^{1}$ 'A growing crisis: disadvantaged women and their children', US Commission on Civil Rights, May 1983, http://babel.hathitrust.org/cgi/pt?id=uiug.301 $12075^{6} 34441$; view=1 up; seq=1, pp. 27-33.

$4^{2}$ Eleanor Smeal, 'Sex discrimination in the work place', 28 Jan. 1981, NOW papers, $\mathrm{MC}_{496}$, box 201 , folder 24, p. 7 .

43 'Women and politics', p. 3 .

44 Ann Lewis, 'Return of the gender gap-just in time for November', Ms. Magazine, Jan. 1992.

45 Smeal, 'Sex discrimination', p. 7.

$4^{6}$ 'Ronald Reagan's budget and women', NOW report, [n.d.], NOW papers, MC496, box 89 , folder 11 .

47 The NWRO, a multiracial coalition, operated from 1966 to 1975 , before filing for bankruptcy. On the organization's focus, see the seminal essay by Johnnie Tillman, 'Welfare is a women's issue', Ms. Magazine, May 1972.

$4^{8}$ Judith Shulevitz, 'Forgotten feminisms: Johnnie Tillman's battle against "the man", New York Review of Books, 26 June 2018. 
doorstep and launching a targeted 'feminization of poverty' campaign to encourage anti-Republican sentiment.49 Indeed, in a 1982 interview, NOW's president blasted Reaganomics as a 'direct and frontal assault on women and their economic security' $5^{\circ}$ A White House report that year showed that this strategy was working: 'The fear of losing government benefits appears to be causing women to oppose the administration.' $5^{1}$ An impression that Reagan was moving to weaken, cut back, or abolish federal programmes and laws designed to protect women spread; Congresswoman Patricia Schroeder (D$\mathrm{CO})$ spoke for many when she argued that Reagan had 'all but declared war on women'. $5^{2}$ By 1983 , a 21 per cent gap appeared in a CBS News/New York Times poll when respondents were asked about Reagan's handling of the economy.53 At the same time, NOW was reporting that more than four million women and children had sunk below the poverty line since 1980 because of Reagan's cuts. 54

In this period, an increasing proportion of women became reliant on the welfare state for subsistence, protection, and expansion of opportunity at the very same time as the Republican party was driving a process to curtail it. NOW used campaigns and strategies to spotlight the 'feminization of poverty', attack Reagan and the Republicans on the issue of 'fairness', and encourage Democratic voting as a result. Moreover, the defeat of a central piece of feminist legislation only months before the 1982 midterm elections would lead NOW to couple this approach with what could be termed the 'feminization of politics' strategy.

\section{I I}

At the outset of the 1980 s, the ERA fight commanded the bulk of feminist energies. After women secured the right to vote through the Nineteenth Amendment in 1920, suffragist leader Alice Paul introduced the ERA to Congress in 1923, affirming the Constitution's equal application to all persons regardless of their sex. Perpetually consigned to congressional committee, the ERA was introduced in every Congress from 1923 to 1971 without success. Released from committee shackles in 1971, and swiftly approved by Congress, the ERA passed thirty of the required thirty-eight state legislatures in under one year. However, the pursuit lost considerable steam following the emergence of a powerful and organized opposition movement, led in part by

49 'NOW's response to the attorney general', [n.d.], NOW papers, MC666, box 371 , folder 7 .

$5^{\circ}$ Quoted in 'Views of NOW', NBC Today Show, 11 Oct. 1982.

$5^{1}$ Adam Clymer, 'Warning on "gender gap" from the White House', NYT, 3 Dec. 1982.

$5^{2}$ Patricia Schroeder, 'All but war on women', Houston Chronicle, 6 Nov. 1981.

${ }^{53}$ Hedrick Smith, 'Public's approval of Reagan in poll rising but limited', NYT, 3 July 1983.

54 Judy Goldsmith, speech to the Illinois Commission on the Status of Women, 23 Feb. 1984, NOW papers, $\mathrm{MC}_{496}$, box 201, folder 28. 
the conservative activist Phyllis Schlafly, who raised the spectre of unisex bathrooms and women fighting on the frontlines. 55

Schlafly, who launched the 'pro-family' interest group, Eagle Forum, in 1972, was one of the ERA's principal opponents and derived her authority from an ability to mobilize women at grassroots to support conservative causes. $5^{6}$ Significantly, in order to defeat the ERA, Schlafly and anti-ERA forces were able to link it explicitly to the highly divisive abortion issue. 57 After the remaining states failed to ratify it, Schlafly claimed that she had sealed its defeat by 'deliberately hanging around its neck the albatross of abortion'. $5^{8}$ Polls, however, still showed that a majority of the electorate favoured the ERA; in 1981 , Gallup found that 63 per cent supported it, whereas 32 per cent opposed it.59 And NOW tried to link the ERA campaign with the gender gap's emergence in an effort to mobilize more women into politics. Indeed, while many commentators were predicting that the ERA defeat would be the death knell for feminism, others were persuaded by NOW's claims that it would politicize more women to join the process. A sampling of national headlines suggests this: 'ERA Defeat Prompts New Interest in Elections' (New York Times) and 'With ERA Off Its Back, White House Senses Trouble at Its Heels, Polls Show Women Voting More and Liking Reagan Less' (Washington Post). NOW aimed to reframe the ERA defeat as a catalyst for action, particularly with the 1982 midterms approaching.

In 1982, NOW, a bipartisan organization, began endorsing Democratic men supportive of the ERA over Republican women opposed to it, despite its tradition of not providing endorsements to specific candidates. The most prominent examples were the endorsements of Barney Frank over Margaret Heckler in a Massachusetts House race and Frank Lautenberg over Millicent Fenwick in the New Jersey Senate race. NOW released a report designed to contradict claims that it had become the 'National Organization for Democratic Women', but its policy to endorse Democratic men over Republican women was illustrative of the contemporary political environment. ${ }^{60}$ As the two parties became increasingly polarized on certain issues, the gender gap showed that women, by and large, found a more welcoming home under the Democratic banner. In fact, between the ERA's demise and the welfare state's retrenchment, the 1982 elections represented something of a referendum on

55 Phyllis Schlafly, 'Time is running out on the E.R.A.', Phyllis Schlafly Report (PSR), Feb. 1978, ERAmerica Records, box 124, p. 2.

$5^{6}$ See Donald Critchlow, Phyllis Schlafly and grassroots conservatism (Princeton, NJ, 2005 ).

57 Douglas Johnson, 'The E.R.A./abortion link and how it can be broken', National Right to Life factsheet, 12 Jan. 1984, NOW papers, MC496, box 191, folder 1; Phyllis Schlafly, 'Will E.R. A. make child-care the state's job?’ PSR, Nov. 1975, ERAmerica Records, box 124, p. 1.

$5^{8}$ Quoted in Critchlow, Phyllis Schlafly, pp. 247-8.

59 'ERA gains highest level of support', Miami Herald, 9 Aug. 1981.

6o As NOW pointed out, while 95 per cent of candidates running were men, 20 per cent of NOW's funds went to those 5 per cent of female candidates. Judy Goldsmith, NOW National Conference speech, 1 Oct. $198_{3}$, NOW papers, MC496, box 25 , folder 31 , p. 1 . 
the Reagan administration for many women and the results highlight that the gender gap proved pivotal.

A New York Times election analysis found a gender differential in 73 of 85 state-wide races, deciding the winners in several closely contested governors' races, including Democrats Mario Cuomo in New York, Mark White in Texas, and Richard Blanchard in Michigan, three of the largest states in the country. ${ }^{61}$ Blanchard's race is particularly illuminating. His opponent, Republican Richard Headlee, was not only anti-ERA but during his campaign he had allegedly mocked women for supporting 'women's issues' ${ }^{62}$ In contrast, Blanchard chose the so-called 'Mother of the ERA', former Congresswoman Martha Griffiths, as his running-mate, and treated 'women's issues', such as childcare and welfare programmes, seriously on the campaign trail. ${ }^{63}$ On election day, the gender gap reached 8.5 per cent while Blanchard won the overall vote by 6.8 per cent. ${ }^{6}$ Providing the winning margins in several races also enabled NOW to challenge claims that the gap was only due to Reagan's warmongering image. Certainly, while most Republicans categorically denied that the ERA had anything to do with the gender gap, Reagan himself apportioned blame to it in an interview just before the midterms. Asked about his 'women problem', Reagan responded by saying: 'I have a hunch that part of it has been inspired by the ERA movement. ${ }^{6} 5$ What every top-level official denied, Reagan confirmed, and since governors could not declare war, liberals now had evidence that a gender gap provided victory based on women's issues. Following these results, NOW quickly released an updated booklet: 'Women $d o$ make the difference'.

NOW also pointed to the significance of its 'Countdown Campaign', launched just before the midterms, as further evidence that the gender gap was now a major factor in political calculations. ${ }^{66}$ By monitoring and publishing gender differences in polls, NOW used their 'Countdown Campaign' to raise the value of women's issues and convince the Democratic party to take notice. According to one midterm analysis, the Democrats listened, seeking to capitalize on the gap by urging members to "tailor campaign materials to women, to shake hands in hospital parking lots...and to make sure that women staffers are visible on hustings' ${ }^{6}{ }^{67}$ Accordingly, as NOW reported to its

61 Adam Clymer, 'Women's election role is disturbing to G.O.P.', NYT, 18 Nov. 1982.

${ }^{62}$ Eleanor Smeal, Why and how women will elect the next president (New York, NY, 1984), pp. $14^{-1} 5$.

63 Griffiths played a seminal role in getting the ERA passed in Congress in the early 1970 .

64 Smeal, Next president, p. 15 .

${ }_{5}$ Quoted in Kathy Bonk, 'The selling of the "gender gap"', in Mueller, ed., Gender gap, p. 95 .

${ }^{66}$ With 3 oo full-time staff and over 7 ,ooo volunteers working the campaign, NOW estimated that they raised and spent over \$10 million in the final year of the ERA battle. Toni Carabillo, 'Looking forward: beyond the June $3^{\circ}$ deadline', [n.d.], NOW papers, MC725, box $3^{\circ}$, folder 2, p. 3 .

67 Anastasia Toufexls, 'Waking up to the gender gap', Time, 18 Oct. 1982. 
activists at the beginning of 1983 , the ERA campaign increased 'our political effectiveness' and allowed women to emerge as a political force 'to be reckoned with'. 68

Having launched its first ever multimillion-dollar advertising campaign, organized campus events, and expanded its door-to-door canvassing project, NOW could point to the success of its ERA rallies in over 180 cities as evidence of its organizational prowess. ${ }^{69}$ Statistics corroborate that the campaign had impressive results on the ground-for example, NOW's membership surged from 4 o,ooo in 1977 to over 220 ,ooo by 1982 ; at the same time, its annual budget climbed from $\$ 5$ oo, ooo to over $\$ 13$ million. $7^{\circ}$ Not only did NOW increase its membership and finances considerably throughout this period, it is clear that it became far more professionalized in the process. In surveying the political landscape after the ERA defeat for example, NOW's Toni Carabillo determined that women had 'learned so many skills we never knew before':

We know political organizing down to the prescient level; we know how to raise money-we're experts on direct mail and fundraising phone banks; [and] we have the largest liberal mailing list of any organization in the country...The reality is the long struggle has only made us larger, stronger, and more skilled. ${ }^{71}$

NOW's ability to turn what was still a crushing defeat into a political launch pad for women evidenced their newfound prowess. Understandably, frustration about their inability to convince male-dominated state legislatures to pass the ERA led NOW to question its position in politics. In a report on the ERA's demise, NOW declared that 'we must elect many more feminist women to sit in the legislative halls of this nation'. ${ }^{72}$ To do so, NOW launched a number of PACs to raise money for these campaigns, establishing forty-six new PACs in twenty-seven states to boast a total of more than eighty across the nation by the 1982 elections. 73

Results were immediate as record-breaking numbers of women filed for legislative seats in 1982. As the Los Angeles Times observed, 'NOW, battered in the ERA fight, appears to have taken a good deep breath and regrouped'. 74 The promise to 'Remember in November' after the ERA defeat became 'We'll remember every November' as NOW used the energy from the 'Countdown

68 NOW letter to activists, 1o Jan. 1983, NOW papers, MC496, box 203, folder 7 .

69 Betty Cuniberti, 'NOW turns to TV to push ERA', LAT, 12 Oct. 1981. A coalition of eight women's groups - including ERAmerica and NWPC - joined the media blitz. 'Women today', 8 Mar. 1982 , NOW papers, MC496, box 126 , folder 8, p. 25.

$7^{\circ}$ NOW National Conference booklet, 8-10 Dec. 1982, NOW papers, MC496, box 21 , folder 9 , p. 15 .

$7^{1}$ Carabillo, 'Looking forward', p. 4.

$7^{2}$ NOW board meeting minutes, 10-11 Dec. 1983, NOW papers, MC496, box 5 , folder 41 .

73 'Women and politics', p. 8; Martin, The other eighties, p. $15^{\mathrm{o}}$

74 Beverly Beyette, 'NOW's time, say feminists promoting vice presidential candidate in ' 84 ', $L A T, 3$ Oct. $198_{3}$. 
Campaign' to drive its strategy, increase its clout, and mobilize turnout.75 Having honed their political skills in the losing campaign for ERA, NOW and its allies had particular success in several states where the ERA had been contested until the ratification deadline, including Florida, where women doubled their number in the state senate from four to nine. $7^{6}$

Portending significant electoral trouble ahead for the Republicans, an internal party report demonstrated that in 1980 and 1982 , for the first time ever, women cast more votes than men in all but one of the twenty-five largest states. Particularly in the South, the report found that the number of women voters in the southern states grew, from 49.8 per cent in 1978 to 55.9 per cent in 1982, and strategists argued that national trends demonstrated that women now held the key to success in future elections. 77 With the emergence of the gender gap, the defeat of the ERA, and the impact of the feminization of poverty campaign, NOW clamoured for a new kind of politics: one that, importantly to them, featured more women in positions of power. They also began seriously to discuss an audacious concept-placing a woman on a major nationwide ticket. According to Smeal, while the 1970 os was the decade that women increased their participation in the workforce, the 1980 os would be the decade that they did so in politics. $7^{8}$

\section{V}

In October $198_{3}$, NOW organized a symposium in Washington DC on 'Women in politics' and invited the full field of Democratic presidential contenders. One question proved more significant than any other: 'Would the candidates pledge to name a woman running-mate?' NOW justified this interest in a woman nominee with reminders of the gender gap and the potential excitement level that such a candidacy might elicit. NOW's new president, Judy Goldsmith, made it clear that the promise to name a woman running-mate would be considered alongside a host of issues to justify the organization's first endorsement of a presidential candidate in its seventeen-year history. When the candidates met NOW, they all claimed that they would give serious consideration to the proposal. Former Vice-President Walter Mondale, for example, described himself as a 'feminist', while Senator Gary Hart (D-CO) declared that he would be proud to serve on a ticket with a woman 'at either end'.79 Not a year had

\footnotetext{
75 Judy Goldsmith, NOW National Conference speech, 30 Sept. 1983, NOW papers, MC496, box 21 , folder 10 .

$7^{6}$ Press release, 'Progress for women in 1982 elections with significant gains in ERA states', 4 Nov. 1982, NOW papers, MC666, box 361 , folder 9.

77 Report in David Broder, 'Reagan's “gender gap” seen widening', WP, 8 Aug. 1983.

$7^{8}$ Eleanor Smeal, 'Women and politics: the long road', Eleanor Smeal Report (ESR), 10 June 1983, ESR Collection, Schlesinger Library, Cambridge, MA, p. 1.

79 Presidential candidate forum, NOW National Conference, 1 Oct. 1983, NOW papers, $\mathrm{MC}_{496}$, box 25 , folder 34 , pp. ${ }^{12-} 5^{8}$.
} 
passed when on 17 July 1984 New York Congresswoman Geraldine Ferraro became the first woman nominated as vice-president by a major political party. Ferraro, addressing the crowd at the Democratic convention that year, spoke to the historic nature of her candidacy: 'by choosing a woman to run for our nation's second-highest office, you send a powerful signal to all Americans...If we can do this, we can do anything. ${ }^{80}$ For many, this signalled a significant advance for women in politics; however, for a dedicated few in the crowd, this was also the culmination of a year of campaigning.

The origins of Ferraro's vice-presidential nomination lay in both the ERA defeat and the electoral significance of the gender gap. As Goldsmith declared to the Democratic convention in 1984 , the move to get a woman on the ticket was grounded in the political realities of the time: 'recognizing both the historic movement of women onto center stage of the political arena and the strong and growing public support for a woman vice-president' ${ }^{8}{ }^{81}$ Described by Goldsmith as 'possibly the most significant political phenomenon of this century', the gender gap enabled NOW and its allies to use the emerging voting clout of women as leverage to convince the Democrats to take notice. ${ }^{82}$ For example, the NWPC organized its own conference in 1983 and invited the Democratic field. Previously, those invited would simply send position papers, or even their wives to the conference, but apparently impressed by the gender gap, five male contenders agreed to appear. One NWPC member called this a 'quantum leap' in women's influence. ${ }^{83}$

With growing influence came increasing calls for a seat at the top of the table. Citing the gender gap as evidence, NOW argued that adding a woman to the Democratic ticket would strengthen it by widening its political reach. Since there had never been a female nominee, this was a dubious claim, but by linking it to increasing participation and voter turnout, the idea of a woman vice-president began to take hold. ${ }^{8}$ Reinforcing this impression that women could determine the outcome, Census Bureau data estimated that eight million more women than men were projected to vote in $1984^{85}$

Despite the fact that women served in positions of power across the world at the time, Mondale pledged only to 'seriously consider' a female running-mate. But this assurance still proved enough for NOW, who endorsed him in

\footnotetext{
8o Geraldine Ferraro, Democratic National Convention speech, 19 July 1984, NOW papers, $\mathrm{MC}_{49} 6$, box 201 , folder 36 .

${ }^{81}$ Judy Goldsmith, Democratic National Convention speech, 18 July 1984, NOW papers, MC496, box 201, folder 36 .

${ }_{2}^{8}$ Judy Goldsmith, NOW National Conference speech, 1 Oct. 1983, NOW papers, MC496, box 201 , folder 36 , p. 1 .

${ }^{83}$ Quoted in Flora Davis, Moving the mountain: the women's movement in America since 1960 (2nd edn, New York, NY, 1999), p. 420.

${ }^{84}$ Judy Goldsmith, NOW National Conference speech, 30 June 1984, NOW papers, MC496, box 201, folder 36 , pp. 8-9.

${ }^{8}$ Judy Goldsmith, letter to NOW endorsed candidates, 2 July 1984, NOW papers, MC496, box 100 , folder 35 .
} 
December $1983 \cdot{ }^{86}$ In justifying this endorsement over the rest of the field, especially Jesse Jackson, who had the strongest programme on women's rights and social justice issues and was the only candidate actually to 'promise' to choose a female running-mate, NOW pointed to the perceived electability of Mondale. ${ }^{87}$ Both the endorsement and this use of electability as a criterion for support demonstrated the distance NOW had travelled in a relatively short space of time. ${ }^{88}$ In common with several women's rights groups, NOW was formed as a bipartisan organization in the mid-196os, yet the polarized nature of the Reagan years had pushed it in a more partisan direction, driving the organization to establish clear institutional links with the Democratic party. While some quarters of its membership had pushed for the organization to use its first ever presidential endorsement to make a radical statement, Smeal reasoned that an overarching determination to defeat Reagan was at the core of the endorsement decision; that by choosing Mondale, activists could solidify behind a frontrunner early and work within a wider coalition to 'turn out the gender gap'. ${ }^{89}$ The outcome of the primary contest demonstrated the wisdom of this strategy: Mondale secured the nomination and Ferraro became the vice-presidential nominee. The test, however, was for NOW to deliver the women's vote as promised.

To do so, NOW organized an extensive registration drive and set out to raise over \$3 million through its PACs. $9^{\circ}$ Working together with the Women's Vote Project, the Leadership Conference on Civil Rights, and other liberal organizations, NOW formed a coalition that specifically targeted women and minorities. ${ }^{91}$ Arguing that 'registration is the key to mobilizing the power of the gender gap', NOW combined this drive with a new campaign, the 'Women's

\footnotetext{
${ }^{86}$ NOW national board resolution on Mondale, 10 Dec. 1983, NOW papers, MC496, box 5 , folder 41 .

87 Still, some critics argued that the choice not to endorse Jackson was part of an underlying racism inherent in both the organization and the Democratic party; a reality also evidenced in the primary campaign, where gender gaps quickly evaporated and were replaced by 'racial gaps', with white women and white men largely voting together against Jackson. In the New York primary, for example, black women supported Jackson 89 per cent and black men 83 per cent, while white women and white men each gave Jackson only 6 per cent of the vote. Miriam Louie and Gloria Quinones, 'Women's stake in the Rainbow Coalition', The Black Scholar, 15 (1984), pp. 27-32.

88 'The candidate we support can win' was point four of a confidential four-point priority plan justifying NOW's endorsement. The rest: (1) Candidate's position on and priority of women's issues; (2) Number of women in key staff positions; (3) Willingness to select a woman vice-president. Memo from NOW/PAC to Judy Goldsmith, 12 Feb. 1984, NOW papers, MC496, box 203, folder 28 .

${ }^{89}$ Eleanor Smeal, 'What NOW's endorsement of Mondale means', ESR, 10 Dec. 1983, p. 3.

$9^{\circ}$ According to NOW, these contributions would close the 'Dollar Gap'. NOW/PAC letter, [n.d.], NOW papers, MC496, box 203, folder 28 .

$9^{1}$ Mary Jean Collins, 'Voter registration', memo to NOW national board, 28 June 1984, NOW papers MC496, box 25, folder 6 .
} 
Truth Squad on Reagan'. $9^{2}$ As an internal memo to its state and local chapters advised, 'Truth Squad' brochures were to be used to 'identify potential antiReagan voters...register them, ask them to join NOW, and re-contact them in [the] fall get-out-the-vote drive'.93 A key facet of this drive was to continue linking Reagan to the welfare state 'crisis'. As previous sections documented, social spending cutbacks provided strong anti-Reagan incentives for millions of women trapped by the increasing 'feminization of poverty'. Identifying this, a strategy document released by NOW argued that only through exercising 'collective power at the polls' could the budget cuts that had 'so heavily and negatively affected women' be stopped.94 Finally, NOW and its allies focused their energy on the states Reagan won by less than 10 per cent in 1980, purporting that registering more women in just a few of them would make the difference in 1984.95

Yet registration drives and targeted campaigns could not undo decades of prejudice. Although Ferraro's candidacy was trailblazing in a number of ways, stereotypes regarding her 'weaknesses' on national security and foreign policy dogged the campaign. As Ferraro later noted, 'it was so endlessly annoying being presumed as weak and indecisive simply because I was a woman' ${ }^{6}{ }^{6}$ To be sure, she likely faced these criticisms not just because she was a woman, but also because she was a liberal woman, particularly as conservatives were increasingly attacking liberals as weak on foreign policy after the Vietnam imbroglio. Yet, what was supposed to be a bold move to exploit the gender gap had instead dissolved into controversy. Come election day, the massive vote that proponents of a female vice-president expected failed to come to fruition. Despite Ferraro's ground-breaking candidacy, the aphorism that people mainly vote the top of the ticket endured. Indeed, as one voter in Cleveland said, 'Ferraro is one hell of a lady. I just wish Reagan was with her.'97 A post-election study also found that 33 per cent of male Democrats who rated Ferraro higher than Mondale on a likeability scale defected from their partisanship to vote for Reagan. $9^{8}$ Mondale was not a particularly popular candidate from the outset and Ferraro's dynamic placement on the ticket may have actually strengthened negative perceptions of him.99 Certainly, Mondale trailed Reagan in most major polls conducted in 1984 and Theodore White's joke that only Florence

$9^{2}$ 'Women's truth squad on Reagan', NOW memo, 17 Feb. 1984, NOW papers, MC496, box 5 , folder 47 .

93 'Truth squad', NOW memo, 5 May 1984, NOW papers, MC496, box 5 , folder 5 o.

94 Judy Goldsmith, 'Role of women in the $198_{4}$ elections', 7 Apr. 1983, NOW papers, $\mathrm{MC}_{49} 96$, box 100 , folder 35 .

95 Registration packet to state chapters, 27 July 1984, NOW papers, MC496, box 203, folder 7 .

$9^{6}$ Geraldine Ferraro, My story (Chicago, IL, 1985), p. 273.

97 Quoted in Martin, The other eighties, p. 155.

$9^{8}$ Arthur Miller, 'Gender and the vote: 1984', in Mueller, ed., Gender gap, p. 266.

99 For detailed analysis of the Mondale campaign, see Steven Gillon, The Democrats' dilemma: Walter F. Mondale and the liberal legacy (New York, NY, 1992). 
Nightingale or Joan of Arc could have saved his campaign effectively captured the mood. ${ }^{100}$

Additionally, after the midterm losses in 1982 , the gender gap took on a new measure of importance for Reagan and the Republican party. Shortly after the midterms, Reagan made two high-profile appointments of women to cabinet positions-Elizabeth Dole as secretary of transportation and Margaret Heckler to head the Department of Health and Human Services. According to the Washington Post, these appointments were driven by political calculations: "The president is seeking to neutralize this "gender gap" by including women in the upper reaches of his administration, according to White House aides.' ${ }^{101}$ The administration also launched 'The Working Group on Women' and Dole was put in charge of publicizing Reagan's new efforts to improve the status of women. As Dole later explained, 'this was the first time we'd had a lot of assistants to the president working on women's issues'. ${ }^{102}$

Moreover, in attempting to bridge the gap, Republicans began to profile women voters, allowing strategists to reject the concept of women as a uniform category and concentrate on finding those subgroups that would be most receptive to the Republican message. Whilst NOW was largely treating women as a monolithic voting bloc to increase its own influence, Republican strategists began to divide women into eight subgroups, named alphabetically from Alice to Helen, the latter being the most anti-Reagan-unmarried, unemployed women under twenty-five. ${ }^{103}$ Writing off the anti-Reagan groups, television ads, direct mail initiatives, and campaign appearances were targeted at the demographic subgroups considered most responsive to Reagan's message. As James Lake, Reagan's campaign press secretary, claimed at the time, "it is foolish for us to try to attract the "Gloria Steinems of America", but certain Reagan initiatives - reversing his opposition to taxes that benefit women, appointing cabinet-level posts, and putting the first woman on the Supreme Court - were designed to appeal to Alice and her friends. ${ }^{104}$

Consequently, by not addressing the issues that underpinned the gender gap for fear of inadvertently alienating male voters, the Mondale campaign left an opening that Republicans were able to exploit. According to journalist Ellen Goodman, the Mondale camp mistakenly believed that Ferraro's presence on the ticket alone would sufficiently motivate women to vote Democratic: 'They played to the women's vote only at the end...It was as if the Mondale people expected Ferraro to win women's votes based on mysticism.' ${ }^{105}$ Additionally,

\footnotetext{
${ }^{100}$ Quoted in James Reston, 'Mondale and who else?', NYT, 24June 1984; polls in Douglas Rossinow, The Reagan Era: a history of the I98os (New York, NY, 2015), p. 173.

${ }^{101}$ Juan Williams, 'President names ex-rep. Heckler as head of HHS', WP, 13 Jan. 1983.

${ }_{102}$ Quoted in Karen Paget, 'The gender gap mystique', American Prospect, 19 Dec. 2001.

103 Ellen Hume, 'Politics '84, GOP women weigh gender gap', Wall Street Journal, 19 June 1984 .

104 Ibid.

${ }^{105}$ Ellen Goodman, 'Yes, Ferraro made a difference', WP, 8 Nov. 1984.
} 
while NOW had been able to convince the party to place Ferraro on the ticket, they were essentially unable to influence the campaign's agenda in any dynamic way afterwards due to Mondale's strategy. ${ }^{106}$ Indeed, although NOW had traditionally operated by pressuring their agenda from the outside, they were clearly manoeuvring from inside the system now. Even Judy Goldsmith, who now travelled with the campaign, admitted that she had assumed 'an insider's role'. ${ }^{107}$ Inevitably, while NOW was establishing important institutional links with the Democratic party, there were clear limits to how far they could push the party to forward their interests.

Nevertheless, NOW could point to the fact that the gender gap persisted despite the existence of factors that should have eliminated it. Although an overall majority of the electorate voted for Reagan, the National Election Study recorded a gap of 8 per cent, with 63 per cent of men and 55 per cent of women voting for Reagan. According to the New York Times, this gender gap cut across several demographic indicators, including race (white vote -4 per cent/black vote -6 per cent) age (18-29 age bracket -6 per cent/30-44 age bracket -8 per cent), and marital status (married -5 per cent/unmarried 13 per cent). ${ }^{108}$ Still, the Democratic party had to face the fact that a majority voted for Reagan, albeit with reservations from more women. As noted, Mondale ran a relatively uninspiring campaign and focused on notions of collective sacrifice, while Reagan's optimistic rhetoric focused on peace, prosperity, and patriotism and voters responded accordingly. Even Mondale reflected afterwards that Reagan 'was selling Morning in America and I was selling a root canal'. ${ }^{109}$

Crucially, however, across Pennsylvania Avenue in the Senate, the gender gap stretched from 5 per cent, allowing Iowa Democrat Tom Harkin to beat a Republican incumbent, to 18 per cent for Massachusetts Democrat John Kerry. ${ }^{10}$ Helping to keep Reagan's coat-tails short, the women's vote proved key in a number of other important local and state-wide races too, including Senate seats in Illinois and Michigan, and the Vermont gubernatorial contest,

${ }^{106}$ NOW did submit a platform report 'Investing in people', and provided testimony to the Platform Committee, but Mondale's campaign was geared more towards tackling the deficit, reforming taxes, and reshaping foreign policy. Judy Goldsmith, Democratic National Convention Platform Committee speech, 12 June 1984, NOW papers, MC496, box 201, folder 28 .

${ }^{107}$ Kathleen Frankovic, 'The Ferraro factor', in Mueller, ed., Gender gap, p. 119.

${ }^{108}$ Support for Reagan - race: white men (68 per cent) / white women (64 per cent) / black men ( 12 per cent) / black women (6 per cent); age: $18-29$ year-old men (61 per cent) / women ( 55 per cent) / $30-44$ year-old men $(62$ per cent) / women ( 54 per cent); marital status: married men ( 65 per cent) / married women (6o per cent) / unmarried men (63 per cent) / unmarried women ( $5^{\circ}$ per cent). David Rosenbaum, 'A good election for poll takers' NYT, 8 Nov. $19^{8} 4$.

${ }_{109}$ Walter F. Mondale, The good fight: a life in liberal politics (New York, NY, 2010), p. 307.

110 Based on their ADA voting records, both Harkin ( 1 oo per cent) and Kerry (85 per cent) were considered quintessential liberals. Ann Lewis, ADA Today, Jan. 1986, www.adaction.org/ media/votingrecords/1985.pdf. 
where NOW had assigned its largest contribution. ${ }^{111}$ NOW immediately released a memo with the headline: 'Gender gap saves Congress and major seats for Democrats'. ${ }^{12}$ With this gender differential in voting now seemingly established, the Democrats had to learn how to cultivate it better at presidential level.

Despite the result, the Ferraro candidacy remained representative of the increased power liberal women's groups like NOW wielded in the early Reagan years. As Smeal declared, 'perhaps the most important outcome of the Ferraro nomination is that when women leaders sit down to strategize, we will take ourselves more seriously. We know how to play the game.' ${ }^{13}$ Indeed, NOW's campaigns helped register 1.8 million more women for $1984 \cdot{ }^{114}$ Certainly, in its use of political influence, access to politicians and the media, and control of information, particularly polling data, NOW demonstrated its development into a major political force. Crucially, Reagan's 1980 victory prompted a change in political approach for NOW, who were transitioning from a confrontational, bipartisan organization pressuring politics from the outside to a coalition-based, partisan body working within the formal structures of power. ${ }^{15}$ By interviewing candidates and making endorsements, NOW employed the tactics that were traditionally associated with interest/lobbying groups such as labour. ${ }^{16}$ Democratic candidates reacted to the prospect of a NOW endorsement in the same way they did to an AFL-CIO one. But many supporters believed that NOW had made a strategic miscalculation in assuming such an insider role, which became a key focal point of the organization's 1985 leadership contest.

Launching a campaign that surprised many observers, previous president, Smeal, criticized her protégé, Goldsmith, for turning NOW into a wing of the Democratic party and promised to return the organization to its more radical past if elected. While not a battle for the soul of NOW, the contest would still signal the movement's direction. Though NOW's national board and state chapters supported Goldsmith by a 2 to 1 margin, Smeal roused delegates at NOW's convention and won by $839-703$ ballots. Smeal did 'take NOW to the streets' by organizing mass marches and pressuring both parties through campaigns afterwards, but the significance of the gender gap and Reagan's 'antiwomen' stance ensured that the organization remained closely affiliated with

\footnotetext{
111 In a close race, Democrat Madeleine Kunin was boosted to victory in Vermont by a 12 per cent gender gap vote. NOW board meeting minutes, 8-9 Dec. 1984 , NOW papers, MC496, box 6 , folder 7 .

112 Ibid.

113 Eleanor Smeal, 'Ferraro euphoria', ESR, 25 July 1984, p. 1.

114 Eleanor Smeal, 'The Ferraro factor', ESR, 12 Nov. 1984, p. 4.

${ }^{115}$ Judy Klemesrud, 'NOW's president: assessing the election', NYT, 27 July 1985.

116 See Jeffrey M. Berry, The new liberalism: the rising power of citizen groups (Washington, DC, 1999); Ronald J. Hrebenar, Interest group politics in America (3rd edn, New York, NY, 1997).
} 
the Democratic party. ${ }^{17}$ Indeed, despite frustration with the organization's influence in 1984 , NOW did not have an alternative political vehicle available to it and the Reagan Era had clearly illuminated the necessity of pragmatic coalition-building. While NOW would still continue to function as a grassroots movement pressuring politics from the outside, Reagan's first term clearly demonstrated that it had also become, for the first time, an institutionalized interest group pursing politics from within.

\section{V}

By identifying the gender gap, publicizing it, and using it as a means of empowerment, NOW and its allies ensured that the gap became part of political calculations in campaigns for decades afterwards. As noted, women's electoral participation reached and surpassed that of men at the same time as the Republican party signalled a shift in its approach to so-called 'women's issues'. Beginning in 1980, a year in which the country moved politically to the right according to historiographical orthodoxy, the political salience of women's issues created a gender gap that started to elect Democrats and oust Republicans at a number of governmental levels - although its impact on the presidency was yet to be felt, particularly as Republican strategists, not Democratic ones, had proven more astute at disaggregating its complexities for national campaigns. Moreover, as the 1982 midterms demonstrated, reducing the welfare state may have proved politically expedient for Reagan but it was also a catalyst for coalition-building that helped galvanize a broad movement to campaign against the so-called 'feminization of poverty'. Contemporaneously, the campaign to nominate a woman vice-president showcased the increased power that women's groups now wielded in the political arena.

For NOW, the gender gap debate enabled the organization to develop more politically sophisticated operations, particularly with regards to electoral activism and establishing ties with the Democratic party. Indeed, by working with the party, NOW developed coalition-building strategies and mobilized voters throughout Reagan's first term, thus making the absence of women in politics a more potent issue. As a result, they increased their financial and political reach, steadily entrenching their operations and working closely with key legislators to advance movement goals. By the end of Reagan's first term, and in large part because of the strategies implemented by NOW, women had increased their political visibility and legitimacy considerably, and with lasting impact. Indeed, as a consequence of the groundwork laid by NOW, the number of women in the House of Representatives more than doubled

117 Klemesrud, 'NOW's president'; 'Judy Goldsmith versus Eleanor Smeal', June-July $198_{5}$, NOW papers, box 216 , folder 22. 
between the elections of 1980 and 1992, expanding from twenty-one to fortyeight, and the tally of female US senators went from two to seven. ${ }^{118}$

Crucially, greater political participation rates among women fuelled these developments and were the direct result of NOW's voter registration drives in the years prior; between 1980 and 1984, women accounted for 6o per cent of newly registered voters and 'Democratic women accounted for most of that increase.'119 As an internal report by NOW noted, women were now 'more likely than men to support candidates with an activist view of government against candidates who think government is too big' - a clear philosophical preference that favoured the Democrats. ${ }^{120}$ By the end of Reagan's presidency, polls demonstrated that women were now 'more inclined to vote for Democrats, even male Democratic incumbents, over female Republican challengers'. ${ }^{21}$

Therefore, by exploring how NOW developed sophisticated political operations in the 1980s, working in broad coalitions with key liberal officeholders to push back conservative efforts to undo past liberal gains, this article provides a valuable addition to current historiography. It offers a fresh perspective on the decade that counterbalances the prevailing notion of liberal decline by showcasing the dynamic ways in which organizational groups adapted their tactics and political framing to affect change and address the challenges of the Reagan Era. Clearly, the declension narrative is insufficient for capturing both the creativity and effectiveness of organizations like NOW. Rather, the emergence of the gender gap offered NOW a new coalition-building opportunity and they developed several effective mobilization strategies as part of an effort to use the gap as a means of liberal empowerment. Thus, while the gender gap is a complicated phenomenon that continues to affect US politics, the fact that women became 'more liberal and more Democratic' in the 1980 s is an important and often overlooked aspect of Reagan's America.

118 See 'Summary', CAWP.

119 'Women and politics, election '88', NOW report, July 1988, NOW papers, MC666, box 370 , folder 13 , p. 1 .

120 Ibid., p. 18.

121 Paget, 'Gender gap mystique'. 